\title{
Revitalization of Education for Children in Indonesian Families During the Covid-19 Pandemic
}

\author{
*Ahmad Muradi, Universitas Islam Negeri Antasari Banjarmasin, South Kalimantan, Indonesia, \\ ahmadmuradi@uin-antasari.ac.id \\ M. Syahran Jailani, Universitas Islam Negeri Sulthan Thaha Saifuddin Jambi, Jambi, Indonesia \\ Sufyati HS, Universitas Nasional Jakarta, DKI Jakarta, Indonesia \\ Ismail Suardi Wekke, Graduate Program, Institut Agama Islam Negeri (IAIN) Sorong, West Papua, \\ Indonesia, Jusuf Kalla Research Center for Bugis and Makassar Culture, Universitas Muslim Indonesia \\ Hasni Noor, Universitas Islam Negeri Antasari Banjarmasin, South Kalimantan, Indonesia \\ *Corresponding Author
}

\begin{abstract}
In Indonesia, three institutions are responsible for the sustainability of education, namely family, school, and society. Since a child enters school age, the responsibility for his/her education is left to the school, without eliminating his/her family. During the Covid-19 pandemic, it seems as if the role of education is left to the family, which is forced to accept and support the government's efforts. This article would examine literature and opinions regarding strengthening the role of education in the family during the Covid-19 pandemic. The purpose was to find out what the role of the family is in the educational process of children at home during the Covid-19 pandemic as a form of harmonious cooperation with schools and what families should do to strengthen education during the Covid-19 pandemic. The study found that the role of the family to strengthen education at home was to motivate, guide, and assist children in participating in learning at home, realize their obligations and responsibility for education for their children, and support all directions from the government, schools, and teachers regarding the learning process at home.
\end{abstract}

Keywords: Aggressor, Empathy, Aggressive Behaviour, Interpersonal reactivity index Received: 09.12.2020 Accepted: 10.01.2021 $\quad$ Published: 07.02.2021

\section{INTRODUCTION}

There are many articles on educational revitalization that reveal how to strengthen one aspect of education, such as character education, environmental education, Islamic religious education, science education, modeling, and many more. This article represents a study and a reflection on the education experienced by children in their families during the Covid-19 pandemic. Strengthening education in the family needs to be done because the Covid-19 pandemic has changed the educational process that has been in effect so far from school to family or home. In this case, two problems emerged to address: "What is the role of families in the educational process of children at home during the Covid-19 pandemic as a form of harmonious cooperation with schools?" and "What families should do to strengthen education during the Covid-19 pandemic?" This study attempted to examine these two problems.

The Covid-19 pandemic has changed the structure of the education process that has long been in effect worldwide, including Indonesia. Children are now required to study at home, just as parents "forced" to work at home. This condition requires parents to become teachers or, at least, learning guides for their children at home.

Parents who have knowledge of digital, electronic, and internet technology will be able to adapt to this new order. They can compensate for changes in the educational process for their children at home by utilizing gadgets or android smartphones to provide tutoring because assignments and learning references are obtained from these media. Problems arise in parents who have limited knowledge related to technology. This is the problem at hand.

This problem regarding the role of parents/family can be overcome. In some schools, in this case, teachers do not require their students to submit their assignments using gadget media but ask them to do so directly to schools on certain days and hours. There are also some teachers who take the initiative to visit their students in villages or remote areas. Of course, this cannot reduce the role of the family in education at home.

Schools as institutions that provide education have taken over family responsibilities because families are very limited in providing their experiences for their children. As is well known, the 
institutions that play an important and responsible role in children's education are family, school, and community. The family as the first institution has the main responsibility for the educational process of children. The family will raise a superior generation as long as their education is given attention. Family plays a very important role in the educational process. Even, according to Novi Widiastuti et al. (2020), parents or family play a role in the children's achievement of learning outcomes.

As already mentioned, many studies on the revitalization of education have been carried out. For example, Sofyan Sauri (2011) stated that value education is an approach that emphasizes the cultivation of social values in students. Sauri emphasized value education, which includes the values of life that are related to science education. Meanwhile, the authors in the article you are reading emphasize the role of the family in strengthening education for children, especially during the Covid-19 pandemic.

Purwanti (2009) stated that family functions need to be strengthened to avoid the negative impacts of technological developments. The purpose of Islamic religious education here, according to Purwanti, is the development of Islamic religious values (Purwanti 2009). Meanwhile, in this article, we would focus on the educational process for children carried out by families during the Covid-19 pandemic.

Nata (2012) focused on the aspect of character education, by saying that one of the factors causing the character education crisis is that education does not focus on its main goal, namely the development of the three domains of education: knowledge, attitudes, and skills. In fact, it only put forward knowledge from the other two realms. Indeed, the true purpose of education is the realization of the development of these three domains of education. In Islamic education, what is prioritized is the formation of noble morals in humans (Noor, \& Ahmad, 2009). Meanwhile, our article would focus on strengthening education played by the family and cover all areas of education.

In line with Nata, Sunarso (2020) said that the moral crisis that occurred returned to the world of education. According to him, character education taught to students is merely focused on textual basis and does not touch on application in life. Education should not only be left to schools, but also to families who also have a very important role. Students see and interact more with family at home than with teachers at school. Therefore, the family is the first school for children and its role needs to be strengthened.

\section{Research Methods}

This research was a literature review with a descriptive qualitative approach, the results of which would be presented in a narrative form based on the data found (Moleong 2010). The object of this research is the education of Indonesian families during the Covid-19 period. The data collection method used was documentation (Sugiono 2010). This article would explore steps done by families to strengthen education for their children in a theoretical-applicable way during the Covid-19 pandemic. Therefore, theories and opinions related to education in the family were the primary data, which were then analyzed using discourse analysis and then deductively concluded.

\section{LITERATURE REVIEW}

\section{Nature, Role, and Function of Family}

\section{Family Nature}

According to the Law on population development and family development number 52 of 2009 Chapter 1 paragraph 6, the family is the smallest unit in a society that is consisting of husband and wife; or husband, wife, and children; or father and child (widower), or mother and child (widow). This definition of family is more to the individual and the relationship between fellow individuals in one house.

Puspitawati (2013) concluded that the family is the smallest socio-economic unit in society and is a primary group consisting of two or more people who have a network of interpersonal interactions, marital relationships, and adoptions. The definition of family according to Puspitawati is not much different from the definition of family from Law number 52 of 2009, which is related to individual relationships in one family unit. However, Puspitawati's definition is added with the word 'adoption'. So, the definition of family is extended here.

Lestari S. (2016) in her book "Psikologi Keluarga: Penanaman Nilai dan Penanaman Konflik" in the Family said that the family is a household that is related by blood or marriage or provides the implementation of basic instrumental functions or expressive functions of the family for its members who are in one network. 
From some of the family definitions above, it can be concluded that the family is the smallest unit of society in which there are individuals who are related by blood or marriage or a relationship that is legalized by the state with emotional and material support and the fulfillment of certain roles.

\section{Family Role}

As previously stated that the family is the smallest unit of society consisting of father and mother or father, mother and child, this article determined a limitation that the families to be addressed in the study is those having children or dependents in education. Therefore, the role of the family here includes at least the role of education for family members and the role of maintaining children's growth and development (Ulfa, 2020).

Ruli explains (2020) that the role of parents towards children related to education is divided into two fields, namely religious education and social education. Religious education is related to the embedment of faith, habituation of children in carrying out worship to Allah Almighty, and social education related to embedding good behavior and good morals towards the good environment, the family environment, the school environment, and the community environment.

In the Quran, there are instructions regarding religious education, especially the embedment of faith, as in the QS. Luqman verse 13, which teaches children to maintain monotheism to Allah and not to fall into shirk. Meanwhile, social education in the Quran, such as in the letter Luqman verse 19, is related to morals, namely maintaining behavior, especially ethics, walking in public, and lowering one's voice to avoid disturbing others. Every child will have good behavior if they get support from the family (Ulfa, M. 2020). This is where the parents play their role.

Meanwhile, the role of families in maintaining children's growth and development is to maintain children's physical and spiritual health, instill the foundation of a good personality, provide motivation for children to develop themselves, provide good facilities for self-development, and create a safe and comfortable atmosphere for children (Ulfa, 2020). The role of the family in this aspect shows a very close relationship in education, namely in the embedment of personality and providing motivation for children. So it can be said that in the development of children, both the educational aspects and the physical aspects of children's growth and development are inseparable.

\section{Family Function}

There are eight functions of the family according to the National Population and Family Planning Board $(\mathrm{BKKBN})$, namely religion, socio-culture, love, protection, reproduction, socialization and education, economy, and environmental development.

The religous function is a function in which the family provides embedment to its members in relation to faith and religious practices, such as the introduction of family members to the Creator and how to worship properly and correctly. The socio-cultural function for the family is an activity of communication and interaction among family members and is in the form of cultural preservation in the form of life attitudes, values, ethics, and character to the next generation, such as the introduction of the rights and obligations of family members, as well as the embedment of good traditional and cultural values, especially Indonesian culture, which is polite and friendly.

Love function is a function where family members get a good emotional touch so that all of them feel a harmonious relationship. For example, children get attention in the form of praise, appreciation, and advice. The protective function is a function where the family gets a sense of security from all threats, both physical, it can be in the form of a proper place to live or non-physically, in the form of proper food needs.

The reproductive function is a function for the family in channeling its biological aspects legally and lawfully. From this, there is also great hope of getting good offspring. Socialization and education function is a function in which family members get a proper education and can socialize with their environment.

The economic function is a function where the family is obliged to ensure a decent life. Therefore, a father is obliged to earn a living for his family members. The eighth function is the environmental guidance function, namely the family maintains harmony with the environment in the form of cleanliness to maintain health and others.

Regarding how the eight family functions work, Wijayanti, and Berdame, (2019) have conducted a research entitled Implementation of the Eight Family Functions in Central Java Province. The results of this study found that the community that did not know the eight family functions were as many as $88.6 \%$ of respondents. However, from the general results regarding its implementation, on average, more than $50 \%$ of the community performs functions well, especially the socialization and education function. The 
results show a percentage of 87.6 respondents who have carried out this function by sending their children to school and giving children opportunities for additional courses and tutoring.

From the results of this study, it can be said that the socialization and education function of the family had been quite good but needed to be improved. Even, according to Zhang, \& Tang (2020), maximizing family function greatly affects children's learning abilities. Besides, regarding community knowledge, the eight family functions must be continuously socialized.

\section{RESULTS}

\section{Education in Family}

As previously mentioned, a family has a role, function, and responsibility in education. To establish a family, an individual, both as a future husband and future wife, requires full understanding and awareness.

According to Rembangy (2010), the understanding of education is not only related to microeducation, namely the interests of students who are served through the education process, but also macro-education, namely for the benefit of society and even for that of the nation.

According to the National Education System Law number 20 of 2003, education is a conscious and planned effort to create an atmosphere of learning and the learning process so that students actively develop their potential to have religious-spiritual strength, self-control, personality, intelligence, noble character, and good skills needed by themselves, society, nation, and state. According to the National Education System, in the scope of education in the family or micro level, education is a conscious and planned effort. This is the understanding and awareness meant for future husbands and wives to prepare for family life, especially in the educational function.

Wahidin (2019) in his article "The Role of Parents in Fostering Learning Motivation in Elementary School Children" stated that there are five family obligations, one of which is parents are the first place of learning for children (Indrawati, \& Rahimi, 2019). This will affect the development of children in the future. Parents and children must have strong and close relationship.

First, first experiences in childhood. At this time, the role of parents is very important to create a harmonious family atmosphere between parents and children. Therefore, prospective parents who have just acquired offspring/children must understand the knowledge and awareness of the importance of their first experiences with children (Wahidin 2019).

Secondly, parents ensure the emotional life of children. Children need love from their parents. Instinctively, a child asks for attention and love from both parents. Therefore, children's needs are not only in the outward aspects of clothing, food, and shelter but also sympathy and mutual trust, which will create emotional relationships among family members. This is very important for the formation of a child's personality (Wahidin 2019).

Thirdly, instill moral education. A good way to instill moral education in childhood is by modeling, habituation, story, and play (Noor \& Ahmad, 2009). In the exemplary method, children imitate what they do. Therefore, in addition to teachers, parents must also be role models for their children (Maya, 2017). This method is very effective for moral internalization and social-emotional personality formation (Maya, 2017). The habituation method is a general introduction to children about worship and behavior in the form of procedures for doing something because at this time children see and hear what is going on in their environment. Hence, from there, a good habit will be created for them. The story-telling method is to convey messages through stories or fairy tales. Children really like stories, especially if the stories are appropriate for their age and contain good lessons for them. The last is the playing method, which is a fun activity for children. This playing method is done to meet the needs of physical-motoric, cognitive, language, and socio-emotional development (Noor, \& Ahmad, 2009). So, here also appears the function of the family, namely the formation of children's personality (Sandarwati 2014).

Fourthly, providing a basis for social education. In the family, it is also very important to lay the foundations of social education in the form of social awareness in children through helping, cooperation, maintaining order and cleanliness (Wahidin 2019), as well as other activities related to human relations in the surrounding environment.

Fifthly, laying down religious foundations. As already mentioned, the role of parents in the family is to meet children's rights in their lives, especially religious bases (Wahidin 2019). Like the methods mentioned above, they are also applied in laying religious foundations for children, such as providing exemplary and habituation in carrying out worship and other religious activities.

If each family plays the role as mentioned above, education through the family will be able to produce humans as individuals and members of society who are healthy and intelligent (Rembangy, 2010). The meaning of education in this family here is the laying of the foundation of the five roles of 
parents/family that have been mentioned above. So, then, the foundation that has been embedded in the child will continue to develop through the school and community environment, both in the national and global scope. As with the purpose of education, if from the start every child gets his rights given to him by the family through his role (Sandarwati, 2014), then the Indonesian generation may have: 1) a strong and religious personality that upholds the noble culture of the nation, 2) awareness of democracy in social, national, and state life, 3) high moral-legal awareness, and 4) quality life, both at the individual, community, and national level (Rembangy, 2010).

\section{The Covid-19 Pandemic and Its Impact on the World of Education}

The Covid-19 Pandemic and Its Impact on the World of Education

The world was jolted, shocked, and at the same time saddened by the Covid-19 epidemic that hit, has destroyed, and is still destroying all sectors of human life. Almost all countries get the impact. Moreover, big countries starting from China (read: Wuhan), Japan, Italy, America, and other countries, including Indonesia.

According to the notes of Andrei R. et al. (2020), initially, there was a report in December 2019 in the Chinese city of Wuhan that there was a virus called the 2019 coronavirus affecting 41 patients with atypical pneumonia with etiology, and rapidly increasing in early January 2020 . These cases were reported to continue to increase and hit more than 120 countries. On March 11, 2020, WHO declared it a pandemic. This virus infection entered Hokkaido Japan, with a confirmed case on January 28, 2020, followed by the second one on February 14, 2020. Furthermore, there were reported as many as 90 cases from February 24 to March 62020 until it was mentioned that there were cases of exports from Japan to Thailand and Malaysia (Andrei R. et al. 2020).

In the UK, according to Docherty AB, et al. (2020) in their article Features of 20133 UK patients in hospital with covid-19 using the ISARIC WHO Clinical Characterization Protocol: prospective observational cohort study that the first patient was confirmed for Covid-19 in the UK at 31 January 2020. The symptoms detected were fever (71.6\%), shortness of breath (71.2\%), cough (68.9\%), and as many as $4.5 \%$ had no symptoms on admission. Some of the other symptoms that can arise from this viral infection, although rare, are diarrhea, headaches, conjunctivitis (red, itchy, and watery eyes), loss of ability to taste or smell, and skin rashes. These symptoms appear within two days to 2 weeks after the patient is exposed to Covid-19. Until January 6, 2021, WHO has recorded 84,474,195 confirmed cases of covid-19 worldwide $1,848,704$ and 222 exposed countries or regions.

Meanwhile, according to Abdullah (2020), Indonesia declared Corona Virus Disease 2019 (COVID-19) as a national disaster on March 2, 2020. Then on March 13, a Task Force for Rapid Responses to COVID-19 was formed in line with the issuance of the Presidential Decree (Keppres) No. 9/2020. Even though two days before that (March 11), the first patient infected with the corona in Indonesia died (Abdullah, 2020). In Indonesia, as of January 6, 2021, the Covid-19 Handling Acceleration Task Force report recorded 779,548 confirmed cases, 645,746 cases recovered, and 23,109 deaths.

The covid-19 case raises threats and fears for the world community, especially the Indonesian people. Abdullah (2020) noted that four traumas are diagnosed following this pandemic, namely 1) individual trauma that appears in the form of "social withdrawal" in which a person suspected of contracting the coronavirus or an employee fired from his work tends to isolate himself from the group and the social environment, 2) individual trauma "hysterical" manifested in extreme expressions out of control, ranging from shouting, hitting him/herself, attacking medics, damaging objects around them, to trying to jump from the window of the hospital treatment room, 3) violent psychological trauma act, which harms children and spouses. Complaints regarding cases of violence, rape, sexual harassment, and online pornography increased sharply after the implementation of social distancing and work from home, and 4) psychological trauma that was "collective attach" in response to the mass panic experienced by the community. impact:

Then, what is the impact of covid-19 on the world of education? The following is the flow of the 


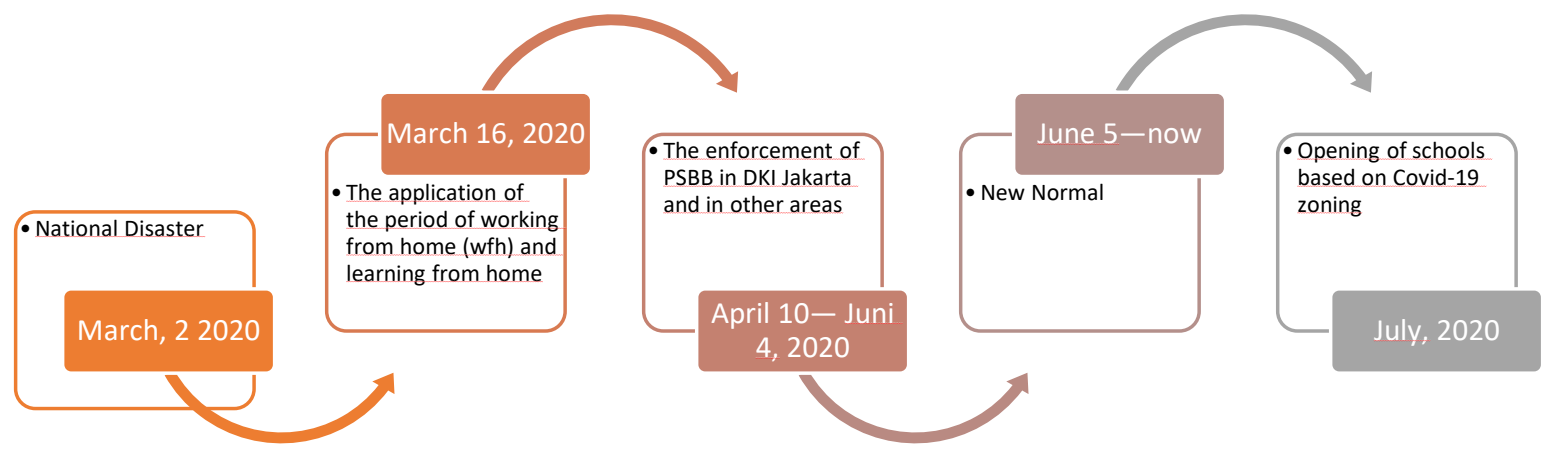

\section{Chart 1. The Impact of Covid-19 on the World of Education in Indonesia}

As in Chart 1 above, since March 16, 2020, there has been a 'lockdown' of schools, and students were required to study at home. The steps taken by the government through the minister of education and culture are implementing online/home learning. Several government steps in the education sector can be seen from the policies taken. First, the issuance of Circular number 2 and number 3 of 2020 concerning the Prevention and Handling of Covid-19 within the Ministry of Education and Culture and in the Education Unit. These two Circular Letters are about health protocols and communication channels that are implemented as an effective form of prevention from spreading and breaking the chain of this dangerous virus. Secondly, the issuance of Circular number 4 of 2020 concerning the Implementation of Education in a Covid-19 Emergency, which is strengthened by a new Circular Number 15 of 2020 concerning Guidelines for Organizing Learning from Home in the Emergency of the Spread of Covid-19. In Circular Number 4 of 2020, there are several government policies related to the National Examination cancellation, school exams, class promotion, admission of new students, assistance funds, and the learning process at home.

Regarding the cancellation of the National Examination, the minister, Nadiem, said, "Nothing is more important than the safety and health of students and their families." Of course, this National Examination cancellation is also related to the abolition of it as a condition for school graduation and for selection to enter higher education levels.

Regarding studying at home, there are several reliefs given by the Ministry of Education and Culture to students and teachers so that the learning process can continue. The following is the policy stipulated by the Minister of Education and Culture based on Circular Number 4 of 2020, namely: 1) online/distance learning is carried out to provide a meaningful learning experience for students, without being burdened with demands to complete all curriculum achievements for class promotion and graduation, 2) learning at home can be focused on life skills education, among others, regarding the covid19 pandemic, 3) learning activities and assignments can vary between students, according to their interests and conditions, including considering gaps in access or learning facilities at home. In addition, the Ministry of Education and Culture's support for the learning process at home is also provided in the form of a 'Learning from Home' program on TVRI for PAUD, SMP, SMA, SMK, teachers, and parents. The program also presents information related to the appreciation of Indonesian culture during the Covid-19 pandemic. According to Hasanah et al. (2020), the Covid-19 outbreak has presented special challenges for the world of education, especially educational institutions. Anticipating the transmission of the virus, the government has issued various policies, such as isolation, social and physical distancing to large-scale social restrictions (PSBB). This condition requires residents to stay at home, work, worship, and study at home.

The description of the Ministry of Education and Cultures responsiveness regarding the continuity of the learning process at home in the face of the Covid-19 pandemic above can be said to be the right step for all parties who feel the impact, namely schools, teachers, students and parents/families of students.

Of course, this disaster is a shock to the world of education, especially to the economically disadvantaged family who are 'forced' to provide time, services, and facilities for children to be able to take part in online/virtual learning. However, inevitably, all families have to go through this period. 


\section{DISCUSSION}

In religious normative terms, in Islam, the obligation to educate children lies and is borne by the parents. As in QS al-Tahrim (66) verse 6:

"0, you who believe, protect yourself and your family from hellfire ..."

This verse can be understood that parents are responsible for protecting their family from fire (hell). According to Quraish Shihab, this verse shows that preaching and education must start with the family. This means that parents (father and mother) are responsible for the children and also their respective partners as each responsible for their behavior (Shihab, 2002). So that the next generation will have knowledge that can bring them to a better condition. (Mulyono, \& Wekke, 2018) namely:

Also in the hadith of the Prophet. What is popular is about the sanctity of children at birth, "No child is born except in al-fitra (Islam), then both parents make him a Jew or Christian or Magian ..." (Narrated by al-Bukhari)

From the hadith above, it can be understood that parents play a role in shaping their children for their future, at least their behavior. Therefore, strengthening education in the family is very important. Related to family duties, Jailani (2014) argued that the family is in charge of creating conditions, in which a continuous educational process in order to create a superior state should occur because the foundation of education lies in the family (Jailani M. S., 2014).

Juridically, the family has a role and function in the field of education, namely is responsible for their children to get a proper education and get guaranteed personal and self-development. Therefore, both religiously normatively and juridically, the family actually has great authority and responsibility for the children of education. So the function and role of the family must be strengthened in the field of education.

However, related to the problems faced by parents and children in using technology at home, Hamlin and Fless (2018) noted the high costs incurred for technology devices, the existence of families who are not familiar with technology, and network access in rural areas. These are obstacles that must be resolved together, especially during the Covid -19 pandemic. The Indonesian government has reviewed and instructed educational institutions at all levels to carry out the learning process at home. In fact, the instructions can be understood that the government gives trust to families to motivate, guide, and assist children in participating in learning at home.

Even though the teachers have provided learning material to students online, the role of the family is very important for children, especially in fulfilling learning facilities. From here, a process that is equally important is communication between teachers, parents, and children.

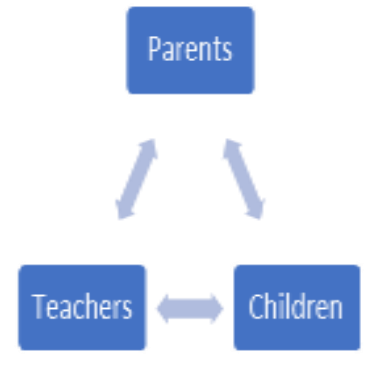

\section{Chart 2. Communication within the framework of the educational process between parents, children and teachers}

While studying from home, some students use smartphones to get materials and exercises that the teacher sends and to send their practice assignments to the teacher. In the process of learning, understanding, and answering the exercises given, the role of the family is very important so that children feel motivation, support, and guidance from their parents. However, in families with shortages, this is a special consideration for teachers in providing lessons and school assignments.

Here the authors found three ways that teachers use in providing lessons and assignments to students. First, for students who are well off and have smartphones (usually in cities) feel less difficulty in following the learning process because of the support of adequate facilities, teachers do not feel significant difficulties in delivering lessons and exercises. Secondly, the teacher provides lessons and assignments to students through the WhatsApp Group (WAG), then the teacher instructs the students to convey this information to friends who are close to their home environment and who do not have 
smartphones. Then, students who do not have smartphones are given a little longer than one week and are invited to collect assignments on Saturdays at school. Thirdly, as we can see on social media, a small number of teachers in rural and remote areas took the initiative to visit their students and teach school materials in their homes. This third method is done every day and each child only gets one meeting per week. Regarding the limitations of the internet for students, the Minister of Education and Culture initiated the Learning-from-home Program (BDR) on TVRI.

The three ways taken by the teachers to interact with their students are the right ways whose main purpose is the delivery of material and the learning process for students. Even the Ministry of Education and Culture has provided relief from the aspect of subject matter, which should only be related to life skills education, health, and empathy, especially regarding the Covid-19 pandemic. And from there the teacher can protect all the different facilities that students have so that learning can take place well. (Wekke, Yandra, \& Hamuddin, 2017)

However, the family or parents still have important obligations as previously stated. Therefore, parents are trying to create good communication between family members for the realization of a good educational process during the Covid-19 pandemic. According to Djamarah (2004), there are four kinds of communication in the family, namely 1) verbal communication, 2) nonverbal communication, 3) individual communication, and 4) group communication.

Verbal communication is communication that is carried out using language. Here, parents can convey something to their children by using oral language. This interaction can take the form of dialogue, laughter, orders, prohibitions, and so on (Djamarah, 2004). This communication is commonly used by parents in the family. However, in the context of education, this type of communication is used according to its proportion and is conveyed as well as possible. Nonverbal communication is the delivery of messages without using language and is useful as a verbal communication amplifier (Djamarah, S. B. 2004). Using a gesture can be a nod of approval, frowning as a sign between agreeing and disagreeing, or a sign of disagreement. Individual communication is communication in interpersonal interactions (Djamarah, 2004), such as between husband and wife, father and child, mother and child, or child and another child. Unlike personal communication, group communication is a communication made by several people in the family who talk about one and another thing.

The four kinds of communication above can be used by parents in interacting with family members, especially in the learning process during the Covid-19 pandemic.

From the description and explanation above, it can be said that the family has responsibility for the learning process of children at home by providing full support to their children to follow and get learning from both the teacher and from people at home. The role of the family as a form of education strengthening at home is to motivate, guide, and assist children in participating in learning at home using the four kinds of communication explained above. The things by families, communities, and the government to strengthen education are 1) raising the parents' awareness of their role and function in education, 2) teacher support for parents in the education process at home, 3) community support for parents in creating a safe and comfortable atmosphere in their respective environment, and 4) government support for parents in the form of providing adequate facilities to support the education process at home.

Covid-19 has opened the inner eyes of every parent that their various experiences so far have left children without adequate attention and guidance: divided love, low motivation, and actions that have not had a positive influence on the children. As primary educators, parents must have high-touch (authority), which is, according to the opinion of Prayitno (2009), a set of interpersonal relationships that links students with educators in educational situations. Through this authority, the relationship between the two is a social relationship that characterizes the uniqueness of the basic educational situation manifested through five main elements, namely (1) recognition and acceptance, (2) affection and tenderness, (3) strengthening, (4) ) educational assertiveness, and (5) direction and example. From there it is expected, the cognitive, affevtive and psychomotor abilities of children can develop properly. (Muradi, Mubarak, Darmawaty, \& Hakim, 2020)

\section{CONCLUSION}

The Covid-19 pandemic is still ongoing today. The government has tried its best to deal with and then to "make peace" with it. In fact, through the Education and Culture Ministry, the government also tries to provide the best service for the continuity of the learning process for students at home. Therefore, this effort must be welcomed and supported by the community, which is, in education, the teacher and parents (family). Teachers and families must support all of these government policies. The Covid-19 pandemic has not dampened the enthusiasm and motivation of parents in fulfilling children's education. 
On the other hand, there are many valuable lessons for parents, including restoring the position and responsibility of parents, especially mothers, as the primary educators in the family.

\section{REFERENCES}

Abdullah, I. (2020). COVID-19: Threat and fear in Indonesia. Psychological trauma: theory, research, practice, and policy, 12(5), 488.

Akhmetzhanov, A. R., Mizumoto, K., Jung, S. M., Linton, N. M., Omori, R., \& Nishiura, H. (2020). Estimation of the actual incidence of coronavirus disease (COVID-19) in emergent hotspots: The example of Hokkaido, Japan during February-March 2020. medRxiv.

Djamarah, S. B. (2004). Pola komunikasi orang tua dan anak dalam keluarga (sebuah perspektif pendidikan Islam). Rineka Cipta.

Docherty, A. B., Harrison, E. M., Green, C. A., Hardwick, H. E., Pius, R., Norman, L \& Merson, L. (2020). Features of 20133 UK patients in hospital with covid-19 using the ISARIC WHO Clinical Characterisation Protocol: prospective observational cohort study. bmj, 369.

Hamlin, D., \& Flessa, J. (2018). Parental involvement initiatives: An analysis. Educational Policy, 32(5), 697-727.

Hasanah, A., Lestari, A. S., Rahman, A. Y., \& Daniel, Y. I. (2020). Analisis aktivitas belajar daring mahasiswa pada pandemi Covid-19.

Indrawati, E., \& Rahimi, S. (2019). Fungsi keluarga dan self control terhadap kenakalan remaja. IKRA-ITH HUMANIORA: Jurnal Sosial dan Humaniora, 3(2), 86-93.

Jailani, M. S. (2014). Teori Pendidikan Keluarga dan Tanggung Jawab Orang Tua dalam Pendidikan Anak Usia Dini. Nadwa, 8(2), 245-260.

Lestari, S. (2016). Psikologi Keluarga: Penanaman Nilai dan Penanaman Konflik dalam Keluarga. Prenada Media. (googlescholar-online)-definsi keluarga ada di ficture-sri 01-04

Lexy, J. (2010). Moleong. Metodologi Penelitian Kualitatif, 163.

M Noor, F., \& Ahmad, M. (2009). Pendidikan Akidah Berbasis Keluarga.

Maya, R. (2017). Revitalisasi Keteladanan dalam Pendidikan Islam: Upaya Menjawab Peluang dan Tantangan Pendidikan Islam di Era Masyarakat Ekonomi ASEAN (MEA). Edukasi Islami: Jurnal Pendidikan Islam, 5(09), 12.

Mulyono, M., \& Wekke, I. S. (2018, July). Academic and Culture Development Strategy Management for Islamic Higher Education In Indonesian. In IOP Conference Series: Earth and Environmental Science (Vol. 175, No. 1, p. 012163).

Muradi, A., Mubarak, F., Darmawaty, R., \& Hakim, A. R. (2020). HIGHER ORDER THINKING SKILLS DALAM KOMPETENSI DASAR BAHASA ARAB. Arabi: Journal of Arabic Studies, 5(2), 177-190.

Nata, A. (2012). Revitalisasi pendidikan karakter untuk mencetak generasi unggul. Didaktika Religia, 1(1). Prayitno, P. (2009). Dasar Teori dan Praksis Pendidikan. Grasindo.

Purwanti, P. (2009) Revitalisasi Pendidikan Agama Islam dalam Keluarga di Era Globalisasi. Guru Membangun, 22(2).

Puspitawati, H. (2013). Konsep, teori dan analisis gender. Bogor: Departe-men Ilmu Keluarga dan Konsumen Fakultas Ekologi Manusia Institut Pertanian.

Rembangy, M. (2010). Pendidikan Transformatif: pergulatan kritis merumuskan pendidikan di tengah pusaran arus globalisasi. Yogyakarta: Teras.

Ruli, E. (2020). TUGAS DAN PERAN ORANG TUA DALAM MENDIDK ANAK. JURNAL EDUKASI NONFORMAL, 1(2), 143-146.

Sandarwati, E. M. (2014). Revitalisasi peran orang tua dalam mengurangi tindak kekerasan terhadap anak. Sawwa: Jurnal Studi Gender, 9(2), 287-302.

Sauri, S. (2011). Revitalisasi Pendidikan Sains dalam Pembentukan Karakter Anak Bangsa untuk Menghadapi Tantangan Global. In Makalah disajikan dalam Seminar Nasional Pendidikan Sains, di Universitas Negeri Yogyakarta.

Shihab, M. Q. (2002). Tafsir al-misbah. Jakarta: lentera hati, 2.

Sugiyono, S. (2010). Metode penelitian kuantitatif dan kualitatif dan R\&D.

Sunarso, A. (2020). REVITALISASI PENDIDIKAN KARAKTER MELALUI INTERNALISASI PENDIDIKAN AGAMA ISLAM (PAI) DAN BUDAYA RELIGIUS. Jurnal Kreatif: Jurnal Kependidikan Dasar, 10(2), 155-169.

Ulfa, M. (2020). Peran Keluarga dalam Konsep Psikologi Perkembangan Anak Usia Dini. Aulad: Journal on Early Childhood, 3(1), 20-28.

Wahidin, W. (2019). Peran Orang Tua Dalam Menumbuhkan Motivasi Belajar Pada Anak Sekolah Dasar. JURNAL PANCAR (Pendidik Anak Cerdas dan Pintar), 3(1). 
Wekke, I. S., Yandra, A., \& Hamuddin, B. (2017, December). Learning Strategy in Class Management: A Reflection from Manado Case. In IOP Conference Series: Earth and Environmental Science (Vol. 97, No. 1, p. 012053). IOP Publishing.

Widiastuti, N., Hartini, S., \& Rakhman, A. (2020). THE ROLE OF A FAMILY IN CONTROLING ENVIRONMENTAL INFLUENCE IN CHILDREN. EMPOWERMENT: Jurnal Ilmiah Program Studi Pendidikan Luar Sekolah, 9(1), 95-99.

Wijayanti, U. T., \& Berdame, D. Y. (2019). Implementasi Delapan Fungsi Keluarga di Provinsi Jawa Tengah. Jurnal Komunikasi, 11(1), 15-29.

Zhang, J., \& Tang, M. (2020). The relationship between family environmental factors and child sensory integration. Journal of Nursing Education and Practice, 10(1). 